\title{
Galanin inhibits leptin expression and secretion in rat adipose tissue and 3T3-L1 adipocytes
}

\author{
R-Y Li ${ }^{\star 1,2}$, H-D Song*2, W-J Shi', S-M Hu${ }^{2}$, Y-S Yang ${ }^{1}$, J-F Tang ${ }^{1}$, M-D Chen ${ }^{1}$ and \\ J-L Chen ${ }^{1}$ \\ ${ }^{1}$ Ruijin Hospital, Shanghai Institute of Endocrinology, Shanghai Second Medical University, Shanghai, China 200025 \\ ${ }^{2}$ Ruijin Hospital, State Key Laboratory of Medical Genomics, Shanghai Second Medical University, Shanghai, China 200025 \\ (Requests for offprints should be addressed to H-D Song; E-mail: huaidong_s@hotmail.com and M-D Chen; E-mail: mingdaochensh@yahoo.com) \\ ${ }^{*}(\mathrm{R}-\mathrm{Y} \mathrm{Li}$ and H-D Song contributed equally to this work)
}

\begin{abstract}
In addition to serving as a fat depot, adipose tissue is also considered as an important endocrine organ that synthesizes and secretes a number of factors. Leptin is an adipocyte-derived hormone that plays a vital role in energy balance. Expression of leptin is regulated by dietary status and hormones. In the present study, we report that galanin, an orexigenic peptide, inhibits leptin expression and secretion in rat adipose tissue and in 3T3-L1 adipocytes. Treatment with galanin $(25 \mu \mathrm{g} / \mathrm{animal})$ induced approximately $46 \%$ down-regulation of leptin secretion at $15 \mathrm{~min}$, followed by 40,37 and $47 \%$ decreases in leptin secretion at 1,2 and $4 \mathrm{~h}$ respectively. Although Northern blot analysis of adipose tissue from the same animals showed that leptin mRNA expression in adipose tissue was unaffected by galanin treatment for $2 \mathrm{~h}$, galanin treatment for $4 \mathrm{~h}$ led to decline of leptin mRNA expression in a dose-dependent manner. Meanwhile, treating the rats with galanin had no effect on leptin mRNA expression in the hypothalamus. The inhibitory action of the galanin on leptin mRNA and protein levels was also observed in vitro. When incubated with $10 \mathrm{nM}$ galanin for $48 \mathrm{~h}$, leptin mRNA expression and protein secretion also decreased in 3T3-L1 adipocytes. On the other hand, galanin was found not only to express in rat adipose tissue, but also to increase about 8-fold after fasting. Based on these data, we speculate that increased galanin expression in rat adipose tissue after fasting may be involved in reducing leptin expression and secretion in fasting rats.
\end{abstract}

Journal of Molecular Endocrinology (2004) 33, 11-19

\section{Introduction}

Obesity is a worldwide health problem directly linked to several disease processes such as hypertension, hyperinsulinemia and type 2 diabetes (Grundy \& Barnett 1990, Friedman \& Leibel 1992). Obesity initially results from a chronic minor imbalance between energy intake and energy expenditure. Leptin, an adipocyte-derived hormone, is a key factor in regulating body weight and energy expenditure and acts in rodents via hypothalamus receptors to inhibit feeding and increase thermogenesis (Zhang et al. 1994, Pelleymounter et al. 1995). After binding to receptors, leptin activates a specific signaling cascade that results in the inhibition of several orexigenic neuropeptides such as neuropeptide $\mathrm{Y}$
(NPY), melanin-concentrating hormone (MCH), orexin and Agouti-related peptide (Agrp) and stimulation of several anorexigenic peptides such as cocaine- and amphetamine-regulated transcript (CART), corticotropin-releasing hormone (CRH) and pro-opiomelanocortin (POMG) (Flier \& Flier 1998, Woods et al. 1998, Schwartz et al. 2000). All these findings suggest that the critical function of leptin seems to be to inform the neurons in the hypothalamus of energy depot levels in the body. Changes in circulating leptin levels can therefore trigger an appropriate response of the central nervous system (CNS) to modulate food intake and metabolism according to the total amount of body fat (Considine et al. 1996) as well as the variations in energy balance (Boden et al. 1996).

Printed in Great Britain 
Leptin synthesis and secretion are regulated by a complex series of neuroendocrine, endocrine and paracrine signals. A number of factors that regulate leptin synthesis and secretion in vivo or in vitro are identified. Insulin, glucocorticoids and tumor necrosis factor- $\alpha$ (TNF- $\alpha$ ) are activators of leptin production, whereas catecholamines, cAMP agonists, and peroxisome proliferator-activated receptor gamma (PPAR- $\gamma$ ) inhibit leptin synthesis and secretion (Murakami et al. 1995, Mantzoros et al. 1996, Slieker et al. 1996, Zhang et al. 1996, Barr et al. 1997, Kirchgessner et al. 1997, Bradley \& Cheatham 1999).

In our recent study (Yang et al. 2003) on the gene expression profiling of human visceral adipose tissue and its secretory functions, we found using dot blot analysis that galanin and its receptors (GalR1 and GalR2), are expressed in human adipose tissue. Thus we hypothesize that galanin expressed in adipose tissue may play a role in regulating leptin expression and secretion. To address this issue, in the present study the observation that GalR1, GalR2 and galanin are expressed in rat adipose tissue was first further confirmed. Secondly, galanin was administered to rats to study its effect on leptin production in vivo. Thirdly, the effect of galanin on leptin expression and secretion in 3T3-L1 adipocytes was also observed. Finally, the expression pattern of galanin in fasting rat adipose tissue was studied to investigate the possible role of galanin-regulated leptin production in energy balance. Our results demonstrate for the first time that galanin inhibits leptin production in vivo and in vitro, and that the increased galanin expression in rat adipose tissue after fasting may play a role in the regulation of leptin expression and secretion in fasting rats.

\section{Materials and methods}

\section{Animals}

Male Sprague-Dawley rats from BK Company (Shanghai, China), each weighing 200-250 g, were used for these studies. Rats were housed in a temperature-controlled room with a ratio of $12 \mathrm{~h}$ light:12 h darkness. Animals were given free access to food and water and were allowed to acclimate for 7 days before the experiment.

Forty animals were assigned to weight-matched groups and each animal in the groups received a single intravenous injection of $0.3 \mathrm{ml}$ saline containing 1, 5 or $25 \mu \mathrm{g}$ rat galanin (Sigma), or $0.3 \mathrm{ml}$ saline control. Blood samples were collected at 15, 60, 120 and 240 min after the injection, and kept frozen at $-20{ }^{\circ} \mathrm{C}$ for RIA of leptin. The rats were killed 2 or $4 \mathrm{~h}$ after treatment. Samples of epididymal fat pads were quickly removed and frozen with liquid nitrogen, then stored at $-80^{\circ} \mathrm{C}$ until being used for Northern blot analysis.

\section{Cell culture}

3T3-L1 cells were grown in Dulbecco's modified Eagle's medium (DMEM) containing 10\% fetal bovine serum (FBS) and were fed every 2 days. Two days after confluence (day 0), the medium was switched to DMEM supplemented with $10 \% \mathrm{FBS}, 10 \mu \mathrm{g} / \mathrm{ml}$ insulin, $0.5 \mathrm{mM}$ 3-isobutyl-1methylxanthine and $1 \mu \mathrm{M}$ dexamethasone. On day 2 , the medium was changed to DMEM containing $10 \% \mathrm{FBS}$ and $10 \mu \mathrm{g} / \mathrm{ml}$ insulin. Beginning on day 4 , the medium was changed to DMEM containing only $10 \% \mathrm{FBS}$, and cells were given fresh medium every 2 days until day 10 . On day 10 , cells were incubated in DMEM containing $0.1 \%$ BSA for $12 \mathrm{~h}$. Cells were then fed fresh DMEM with $0 \cdot 1 \%$ BSA containing the indicated doses of galanin and incubated for $48 \mathrm{~h}$; cells were collected for real-time PCR and Western blot analysis.

\section{Semi-quantitative reverse transcriptase-PCR (RT-PCR)}

To confirm the results of our previous study, semiquantitative RT-PGR was used. First-strand cDNAs were synthesized from total RNA $(3-5 \mu \mathrm{g})$ of epididymal fat pads using oligo-dT in $25 \mu$ l reaction systems. Mouse GAPDH was used as an internal control. The PCR program was designed with initial melting at $95{ }^{\circ} \mathrm{C}$ followed by $28-30$ cycles at $94{ }^{\circ} \mathrm{C}$ for $30 \mathrm{~s}, 56{ }^{\circ} \mathrm{C}$ for $45 \mathrm{~s}, 72{ }^{\circ} \mathrm{C}$ for $60 \mathrm{~s}$, and a final extension at $72{ }^{\circ} \mathrm{C}$ for $10 \mathrm{~min}$. Primer sequences were as follows: GalR1 (forward primer, 5' TGCT TTTGCTATGCAAAGGTTC 3'; reverse primer, 5' TGGGTTCTTTTCTTTAGGATGGC 3'), GalR2 (forward primer, 5' TTCTGCGTCTGTT GGATGCG 3'; reverse primer, 5' TCTACTC GAGGCTGTGCAGTTG 3'), GalR3 (forward primer, 5' CTTTGCGCTCATCTTCGTGTTG 3'; reverse primer $5^{\prime}$ TCTACTCGAGGCTGTGGA GTTG 3'), galanin (forward primer, 5' GCACGG 
TGCAGTAGTAGCTTAG 3'; reverse primer, 5' GGGGGAAGATTCTTTTTAGCGTAG 3') and GAPDH (forward primer, 5' AAATTCAAC GGCACAGTCAA 3'; reverse primer, 5' GTCTT CTGGGTGGCAGTGAT 3’).

\section{In situ hybridization}

In situ hybridization was performed using nonisotopic DIG RNA labeling kit (SP6/T7) (Roche) according to the manufacturer's protocol. Target fragments (galanin) were cloned into PGEM-T easy vector (Promega) and confirmed by automated sequencing. DIG-labeled probes were generated by transcription with $\mathrm{T} 7$ and sp6 RNA polymerase using DIG RNA labeling kit (SP6/T7). To investigate whether the target genes were expressed in adipocytes, 3T3-L1 adipocytes were cultured on slides as mentioned above in cell culture. Then the adipocytes were fixed with $0 \cdot 4 \%$ paraformaldehyde. Hybridization was performed overnight at $68{ }^{\circ} \mathrm{C}$ in a humidified chamber (100 ng digoxigenin-labeled RNA probe in $100 \mu$ l hybridization buffer per slide). The post-hybridization slides were washed in $2 \times \mathrm{SSC} /$ formamide at $68{ }^{\circ} \mathrm{C}$ twice, then in $0.2 \times \mathrm{SSC}$ at $68^{\circ} \mathrm{C}$ twice (each for $30 \mathrm{~min}$ ). The hybridization signals were detected according to the instructions of the Dig Nucleic Acid Detection kit (Roche). To terminate the color reaction, samples were rinsed several times with nucleasefree water and visualized by light microscopy.

\section{Real-time PCR}

To test the expression of galanin in normal and fasting rat adipose tissue, quantitative PGR was performed using TaqMan. Primer sequences were as follows: galanin primers (forward, 5' TACCCC TGCGTGAGAGCAAT 3'; reverse, 5' TCTTCT GAGGAGGTGGCGAA 3') and GAPDH (forward, 5' GTCACGAGGGCTGCGTTCT 3'; reverse, 5' CATTGAACTTGCGGTGGGTA 3'). TaqMan probe sequences were as follows: galanin probe (5' CTCGACAGCGTGCGTGGCATCG 3') and GAPDH probe (5' CCATCAACGACCCGT TCATTGACGTC $3^{\prime}$ ). Reaction temperatures and cycling parameters were as follows: $95^{\circ} \mathrm{C}$ for $15 \mathrm{~min}$, then 50 cycles at $94{ }^{\circ} \mathrm{C}$ for $30 \mathrm{~s}, 58{ }^{\circ} \mathrm{C}$ for $40 \mathrm{~s}$ and $72{ }^{\circ} \mathrm{C}$ for $1 \mathrm{~min}$, then $72{ }^{\circ} \mathrm{C}$ for $10 \mathrm{~min}$. Quantitation was accomplished by comparison with standard curves generated from known amounts of plasmid containing the gene of interest (100-
10000000 copies). Quantitative PCR based on SYBR Green was used to determine the expression of leptin in 3T3-L1 adipocytes. Primer sequences were as follows: leptin primers (forward, 5'GCGAG GCTGCCAGAATTG3'; reverse, 5' CTGCACCG CAGTTTGATG3') and GAPDH (forward, 5' GT CACGAGGGCTGCGTTCT ${ }^{\prime}$; reverse, 5' CATT GAACTTGCGGTGGGTA 3'). Each reaction was run in duplicate. Standard curves for each amplification product were generated from 10-fold dilutions of pooled cDNA to determine primer efficiency.

\section{Northern blot analysis}

Northern blot analysis was performed using non-isotopic DIG Northern starter kit (Roche) according to the manufacturer's protocol. Target fragments (galanin, leptin and GAPDH) were cloned into PGEM-T easy vector and confirmed by automated sequencing. DIG-labeled probes were generated by transcription with T7 or sp6 RNA polymerase using the DIG Northern starter kit. Total RNA was isolated from rat epididymal fat pads by Trizol reagent (Gibco). Ten-microgram samples of total RNA were run in $1.2 \%$ formaldehyde-agarose denaturing gels and transferred to positively charged $\mathrm{N}$ membrane in $20 \times \mathrm{SSC}$, the membrane was then baked at $80{ }^{\circ} \mathrm{C}$ for $2 \mathrm{~h}$. Hybridization was performed at $68{ }^{\circ} \mathrm{C}$ with agitation overnight. The membrane was washed twice with $2 \times \mathrm{SSC}$ and $0 \cdot 1 \% \mathrm{SDS}$ for $5 \mathrm{~min}$ at room temperature and twice with $0 \cdot 1 \times \mathrm{SSC}$ and $0 \cdot 1 \%$ SDS for $15 \mathrm{~min}$ at $68{ }^{\circ} \mathrm{C}$. According to the manufacturer's instructions, the membrane was washed and blocked and then incubated with anti-DIG serum/alkaline phosphatase conjugate. GDP-star was used as the chemiluminescence substrate. Signals were visualized on X-ray film.

\section{Western blot analysis}

Cells were aspirated with a radioimmunoprecipitation (RIPA) buffer (50 nM Tris (pH 8.0), $150 \mathrm{nM}$ NaCl, $0 \cdot 1 \%$ SDS, $0 \cdot 5 \%$ dexoycholic acid and $1 \%$ Nonindex-P-40); $120 \mu \mathrm{g}$ protein were loaded onto a gel, subjected to SDS/PAGE (5\% stacking gel, $12 \%$ running gel) and then electroblotted onto nitrocellulose membranes. Membranes were blocked in Tris-buffered saline (TBS) buffer, $\mathrm{pH} 7 \cdot 6$ containing $5 \%$ skimmed milk power, at $4{ }^{\circ} \mathrm{C}$ overnight, then exposed to anti-leptin polyclonal antibody (Santa Cruz sc-842; Santa 


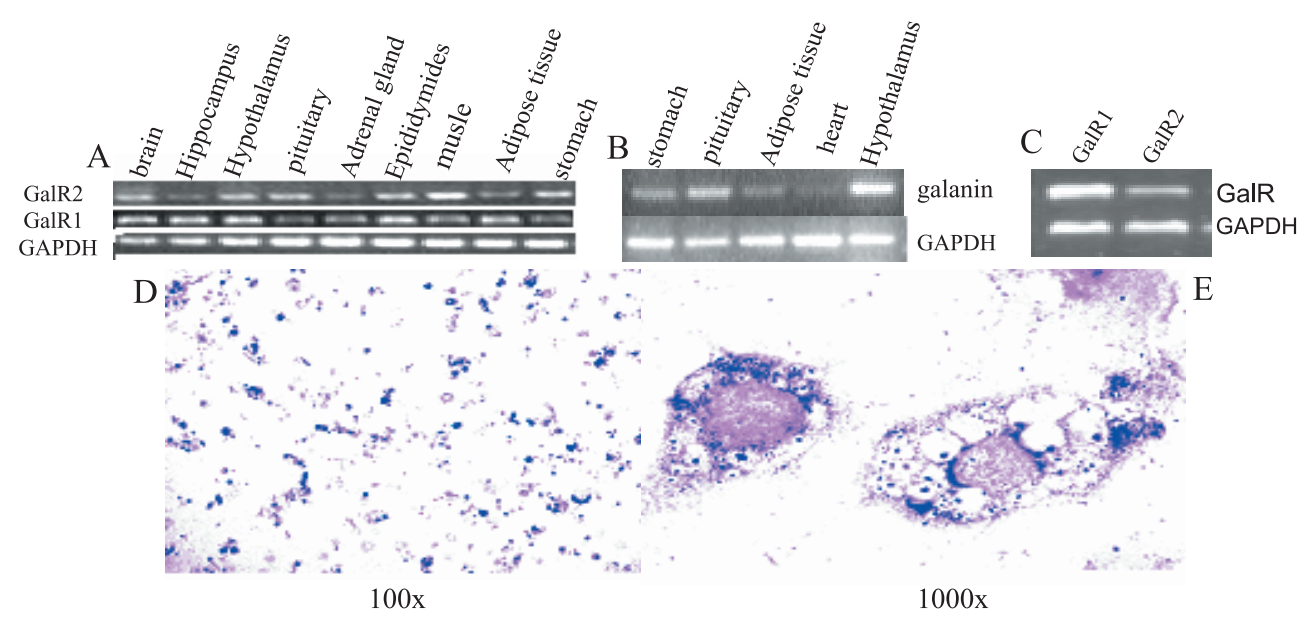

Figure 1 The expression of GalR1, GalR2 and galanin in the rat adipose tissue and 3T3-L1 adipocytes. (A) In RT-PCR analysis, GalR1 and GalR2 were expressed in rat adipose tissue as well as in several other tissues such as hypothalmus and brain. (B) RT-PCR showed the expression of galanin in rat adipose tissue and meanwhile, galanin expression was also detected in other tissues of rat such as hypothalmus, pituitary and stomach. (C) RT-PCR showed the expression of GalR1 and GalR2 in 3T3-L1 adipocytes. (D) and (E) In situ hydridization analysis of galanin expression in 3T3-L1 adipocytes. 3T3-L1 adipocytes were cultured on slides, and hydridized with galanin mRNA probe labeling with non-isotopic DIG. The blue staining shows positive signals. Magnifications: (D) $\times 100$; $(E) \times 1000$.

Cruz Biotechnology, Santa Cruz, CA, USA) or anti-actin antibody (Santa Cruz sc-8432) (at a dilution of 1/200 for anti-leptin antibody and of $1 / 500$ for anti-actin antibody) in TBS-Tween buffer containing 5\% skimmed milk power for $2 \mathrm{~h}$. Membranes then were washed and incubated with anti-rabbit or anti-mouse Ig (DAKO, Carpinteria, CA, USA) conjugated to horseradish peroxidase diluted $1 / 1000$ in the same buffer for $1 \mathrm{~h}$. After a series of washes in TBS-Tween buffer, protein bands were visualized by chemiluminescence with an ECL luminescence kit (Amersham) and exposed to X-ray film.

\section{Leptin quantitation}

Leptin in serum was measured by RIA using a commercially available rat leptin RIA kit (Linco Research, St Charles, MO, USA) as described by the manufacturer.

\section{Results}

\section{The expression of GaIR1 and GalR2 in rat adipose tissue}

The actions of galanin are mediated by at least three subtypes of receptors: GalR1, GalR2 and
GalR3. These receptors have different distributions. Studies were initiated to determine whether galanin and galanin receptors are expressed in adipose tissue and 3T3-L1 adipocytes by using RT-PCR and in situ hybridization. Total RNA was extracted from rat epididymal fat pads and 3T3-L1 adipocytes. Reports to date indicate that galanin receptor mRNA is highly expressed in the hypothalamus (Waters \& Krause 2000). Therefore, total RNA from rat hypothalamus was included as a positive control. As shown in Fig. 1, GalR1 and GalR2 were found to be expressed both in rat adipose tissue and in 3T3-L1 adipocytes. At the same time, galanin was detected both in rat adipose tissue and 3T3-L1 adipocytes using RT-PCR and in situ hybridization. This result suggests that galanin may exert an effect on adipocytes.

\section{Galanin regulates leptin gene expression and leptin protein secretion in vivo}

To analyze whether galanin has an effect on leptin gene expression and secretion in rat visceral adipose tissue in vivo, Sprague-Dawley rats were given galanin intravenously, and plasma samples were collected at $15 \mathrm{~min}, 60 \mathrm{~min}, 2 \mathrm{~h}$ and $4 \mathrm{~h}$ 


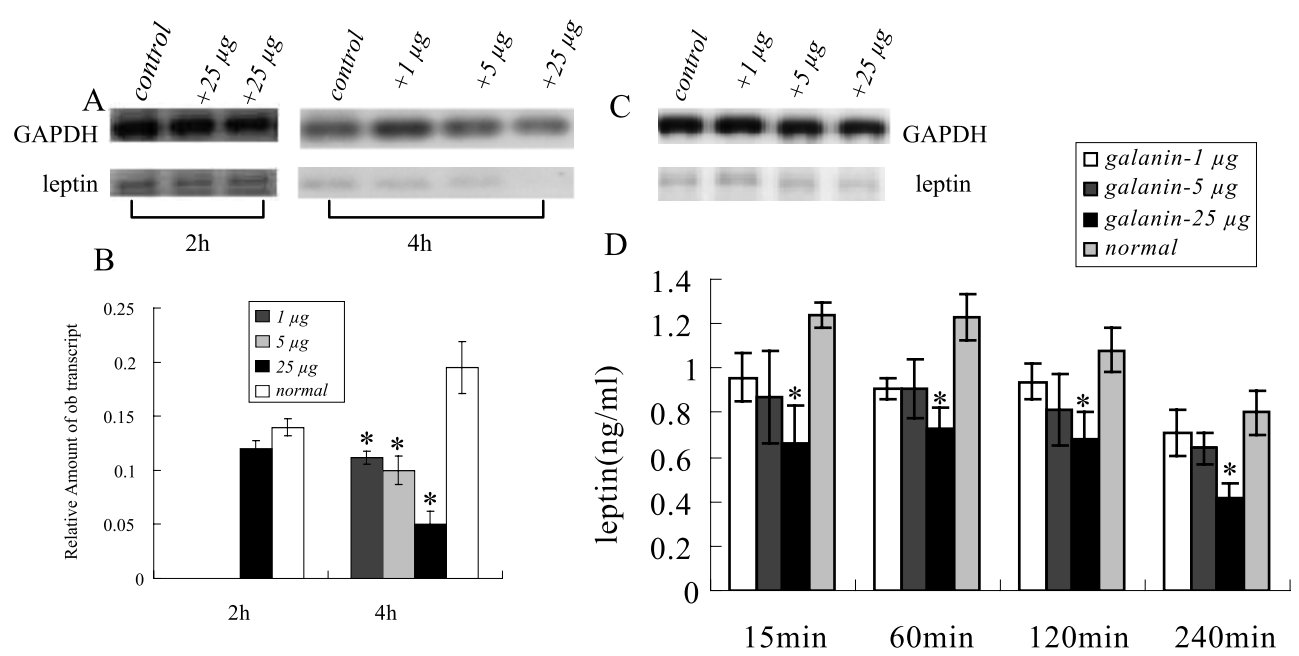

Figure 2 The effect of galanin on leptin secretion and expression in rat adipose tissue. Male Sprague-Dawley rats were given 1, 5 or $25 \mu \mathrm{g}$ galanin or saline intravenously and adipose tissue and plasma samples were taken at different times as described in the Methods. For Northern blot analysis, each lane was loaded with $10 \mu \mathrm{g}$ total RNA from control and fasting rat adipose tissue or hypothalmus. Blots were hydridized with both leptin probe and GAPDH probe. Rat GAPDH was used as a control for RNA integrity and loading. Densitometric scanning was used to determine the relative amount of ob transcript. (A) and (B) Northern blot analysis showing that leptin mRNA expressed in adipose was discovered at $4 \mathrm{~h}$ after treatment with galanin in a dose-dependent manner. Results are means \pm S.E. ( $n=5-6 /$ group), ${ }^{\star} P<0.05$. (C) Northern blot analysis depicting leptin expression in rat hypothalmus treated with 1,5 and $25 \mu \mathrm{g}$ galanin for $4 \mathrm{~h}$. The results show that leptin gene expression in the hypothalmus was unaffected. (D) The effect of galanin treatment on leptin secretion. Rat plasma leptin was measured by radioimmunoassay. Results are expressed as means \pm S.E ( $n=5-9 /$ group), ${ }^{*} P<0.05$.

respectively for later quantitation of leptin. As shown in Fig. 2, treatment with lower doses of galanin $(1 \mu \mathrm{g} /$ animal or $5 \mu \mathrm{g} /$ animal $)$ showed a tendency to decrease plasma leptin levels, although no statistical significance was reached. Treatment with a higher dose of galanin $(25 \mu \mathrm{g} /$ animal) induced approximately $46 \%$ downregulation of leptin secretion at $15 \mathrm{~min}$, followed by 40,37 and $47 \%$ decrease in leptin secretion at 1,2 and $4 \mathrm{~h}$ respectively (Fig. 2D). Meanwhile, Northern blot analysis of adipose tissue revealed that leptin mRNA expressed in adipose tissue was unaffected by galanin treatment for $2 \mathrm{~h}$, although galanin treatment for $4 \mathrm{~h}$ resulted in a decrease of leptin mRNA expression in a dose-dependent manner (Fig. 2A and B). Interestingly, leptin gene expression in the hypothalamus was unaffected by galanin treatment for $4 \mathrm{~h}$ (Fig. 2C). On the basis of these data, we conclude that treating rats with galanin intravenously induces a decrease in leptin expression and secretion.

\section{Galanin regulates leptin gene expression and leptin protein secretion in 3T3-L1 adipocytes}

To determine whether the in vivo changes in leptin production are the result of a direct galanin effect on adipocyte leptin expression, the effect of galanin $(10 \mathrm{nM}, 48 \mathrm{~h})$ on leptin expression and secretion in 3T3-L1 adipocytes was evaluated. As shown in Fig. 3A, treatment with $10 \mathrm{nM}$ galanin for $48 \mathrm{~h}$ induced approximately 50\% decrease in leptin mRNA expression in 3T3-L1 adipocytes. Meanwhile, Western blot analysis demonstrated that leptin protein also decreased in 3T3-L1 adipocytes (Fig. 3B). These results suggest that the in vivo effects of the galanin may be due to a direct cellular effect on leptin production.

\section{Effects of fasting on galanin and leptin expression in rat adipose tissue and on blood leptin levels}

Since galanin inhibits leptin expression and secretion in vivo, additional studies were initiated to 

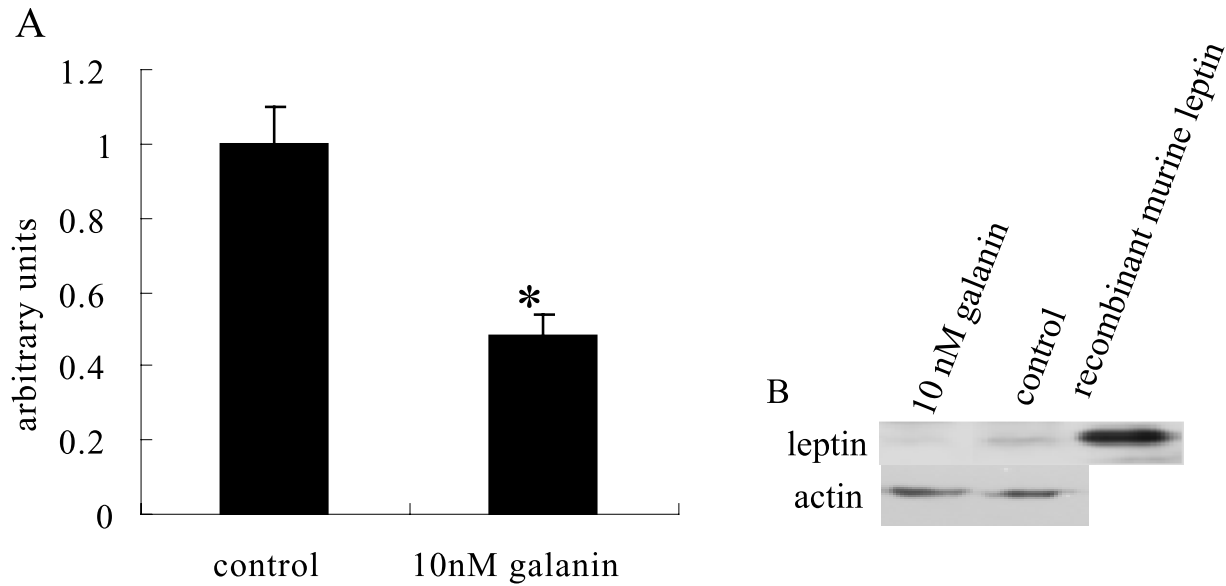

Figure 3 The effect of galanin on leptin level in 3T3-L1 adipocytes. The differentiated 3T3-L1 cells induced by $10 \mu \mathrm{g} / \mathrm{ml}$ insulin, $0.5 \mathrm{mM}$ 3-isobutyl-1-methylxanthine and $1 \mu \mathrm{M}$ dexamethasone were cultured in the presence or absence of $10 \mathrm{nM}$ galanin for $48 \mathrm{~h}$. (A) Real- time PCR showing the expression of leptin in 3T3-L1 adipocytes treated with $10 \mathrm{nM}$ galanin, compared with 3T3-L1 adipocytes in the absence of galanin. GAPDH was used as a normalization control. Results were expressed as means \pm S.E. for two independent experiments ( $n=6 /$ group), ${ }^{*} P<0.05$. (B) Western blot showing leptin protein levels in 3T3-L1 adipocytes. Treatment with galanin resulted in a decline in leptin protein level in 3T3-L1 adipocytes.

determine whether galanin plays a role in the regulation of lepin expression and secretion in fasting rats. To this end, the expression of galanin in the fed rats and in the rats after $72 \mathrm{~h}$ fasting was compared; at the same time, the expression and secretion of leptin were also examined. SpragueDawley rats $(200-220 \mathrm{~g})$ were divided into two groups ( $n=9-10 /$ group). One group had free access to water and food, while the other was fasted for $72 \mathrm{~h}$. The rats were killed, blood samples were taken for RIA of leptin, and epididymal fat pads were collected for semi-quantitative RT-PGR, Northern blot and real-time PGR. As shown in Fig. 4, consistent with other reports (Saladin et al. 1995), leptin secretion and leptin mRNA expression in rat adipose tissue were decreased by fasting, as discovered using Northern blot analysis and radioimmunoassay (Fig. $4 \mathrm{D}$ and E). As expected, the galanin mRNA probe hybridized with a $0.9 \mathrm{~kb}$ transcript from rat hypothalamus RNA, which corresponds to that previously described for galanin (Brann et al. 1993). However, no such hybridization signal was seen with total rat RNA extracted from epididymal fat pads, indicating that galanin expressed in adipose tissue was lower than that expressed in hypothalamus (Fig. 4A). The galanin gene expression was found to increase in fasting rat adipose tissue by using semi-quantitative RT-PGR (Fig. 4B). To further confirm the result, the galanin gene expressed in rat adipose tissue was analyzed by real-time PCR. The result showed that galanin expression increased about 8-fold in fasting rat adipose tissue (Fig. 4C). All of the above data suggest that increased galanin expression in rat adipose tissue after fasting may play a role in regulating leptin expression and secretion in fasting rats.

\section{Discussion}

Adipose tissue has long been considered to serve as a fat depot; however, research in the past decade has demonstrated that it actually plays a vital role in energy regulation and is now considered as a major endocrine organ. Adipose tissue synthesizes and secretes a number of factors, such as leptin, TNF- $\alpha$, resistin and adiponectin, etc. (Hotamisligi et al. 1993, Zhang et al. 1994, Maeda et al. 1996, Kim et al. 2001). Among these factors, leptin is important because of its key roles in energy balance.

Leptin, an ob gene product, as a sensor in monitoring the size of adipose tissue mass, is 

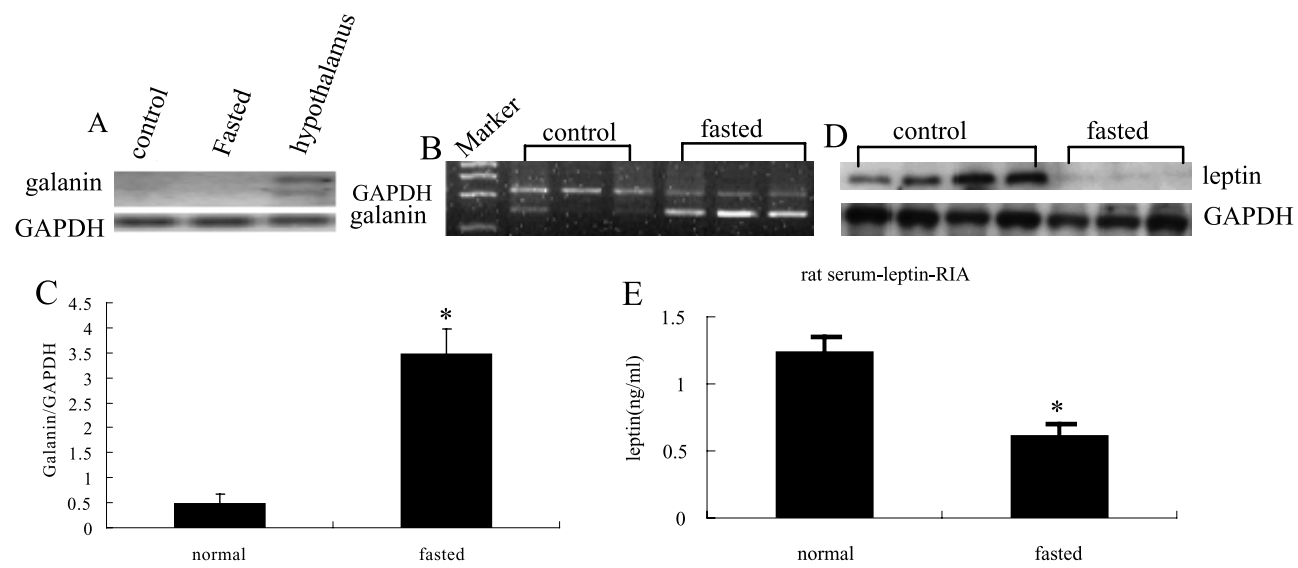

Figure 4 Effect of fasting on galanin and leptin expression and secretion in rat adipose tissue. Male Sprague-Dawley rats were divided into two groups. One group had free access to water and food, while the other had been fasting for $72 \mathrm{~h}$. The rats were killed and blood samples and adipose tissue samples were collected for RIA of leptin and for detecting mRNA expression of these genes. Galanin expression in rat adipose tissue was detected by using Northern blot analysis. Each lane was loaded with $10 \mu \mathrm{g}$ total RNA from control or from fasting rat adipose tissue, $10 \mu \mathrm{g}$ total RNA from rat hypothalmus was used as a positive control. Blots were hydridized with rat galanin probe and then were stripped and reprobed with rat GAPDH probe as a control for RNA integrity and loading. (A) The result showed that the galanin mRNA probe was hybridized with a $0.9 \mathrm{~kb}$ transcript from rat hypothalmus RNA, however, no such hydridization signal was seen in rat adipose tissue. (B) Galanin expression after fasting was detected by semi-quantitive PCR and the result showed that galanin expression was increased in fasting rat adipose tissue. (C) To further confirm the result, galanin gene expressed in rat adipose tissue was analyzed by real-time PCR. The result showed that galanin expression was increased about 8-fold in fasting rat adipose tissue ( $n=14-16 /$ group, $P<0.01$ ). Quantitation was assessed relative to a series of plasmids containing galanin fragment and normalized to GAPDH. As a positive control, leptin expression and secretion were also measured in the same animals. (D) and (E) As expected, both leptin gene expression and protein secretion were decreased after fasting, corresponding to results previously described for leptin. Plasma leptin was measured by RIA, $P<0.01$ ( $n=9-10 /$ group).

transported to the hypothalamus, where it binds to its receptors to regulate expression of other neuropeptides. The information is received and integrated in the CNS processing unit, and then is transmitted by the effector system, including the sympathetic nervous system, to control energy intake and energy expenditure. Furthermore, circulating leptin concentration is decreased in fasting rats and is restored to prefasting levels when rats have been refed for $4 \mathrm{~h}$. The underlying mechanisms regulating leptin secretion have not been fully understood. In the present study, we first found that galanin inhibited ob gene expression and leptin protein secretion in vitro and in vivo. Interestingly, galanin was found not only to be present in rat adipose tissue, but also to increase in rat adipose tissue after fasting. Another interesting finding is that the leptin mRNA expression in rat hypothalamus was unaffected by the galanin treatment. Schwartz's investigation showed that no significant effects were observed in rat hypothalamic levels of preprogalanin mRNA after 24 or $48 \mathrm{~h}$ fasting, and no relationship between changes in body weight and expression of galanin mRNA could be demonstrated (Schwartz et al. 1993). Based on these data, we speculate that increased galanin expression in rat adipose tissue after fasting may be involved in decreasing leptin expression and secretion in fasting rats.

Our results manifest that galanin inhibited leptin secretion at $15 \mathrm{~min}$ and 1,2 and $4 \mathrm{~h}$ after injection. However, Northern blot analysis of adipose tissue from the same animals showed that leptin mRNA expressed in adipose tissue was unaffected at $2 \mathrm{~h}$ after treatment with galanin. These results indicated that the galanin-induced decrease in the 
plasma level of leptin might be mediated by inhibiting leptin release from a pre-existing intracellular pool during the early stages after treatment. Other studies also showed a similar mechanism regulating leptin secretion in rat adipocytes. Kirchgessner reported that treating cultured adipocytes with TNF- $\alpha$ resulted in an acute stimulation of leptin release into the media which were cycloheximide insensitive and brefel$\operatorname{din} \mathrm{A}$ sensitive, and this regulation of leptin secretion was via a secretagogue-like mechanism (Kirchgessner et al. 1997). Another positive regulator of leptin secretion, insulin, may also stimulate leptin secretion via mobilization of preformed leptin pools (Bradley \& Cheatham 1999). The finding that treating rats with galanin for $4 \mathrm{~h}$ causes a decline in both leptin expression and secretion indicates that a sustained effect of galanin on leptin secretion seems to be involved in both transcriptional and post-transcriptional processes.

Galanin is a widely distributed transmitter in the CNS and peripheral tissues (Tatemoto et al. 1983, Merchenthaler et al. 1993). In addition to modulating food intake with a preference for fat after i.c.v. administration into hypothalamus, galanin decreases glucose-dependent insulin release in species other than man (Ahren \& Lindskog 1992), stimulates growth hormone and prolactin release from the anterior pituitary (Chan et al. 1996) and induces smooth muscle contraction in the intestine (Ekblad et al. 1985). The actions of galanin are mediated by at least three G-protein-coupled receptors namely galanin-1 (GalR1), GalR2 and GalR3. GalR1 and GalR2 are highly expressed in the brain with moderate expression in other tissues such as heart, while GalR3 is widely distributed at low or moderate levels in many central and peripheral tissues. GalR 1 plays an important role in feeding behavior as compared with GalR2 and GalR3 (Wang et al. 1998), therefore we deduced that the inhibitory action of galanin was probably involved in GalR1 signaling. However, this presumption needs further study.

It has been proposed that leptin production in adipocytes is regulated by changes in intracellular cAMP levels. In vivo and in vitro studies have shown that an increase in intracellular cAMP concentration induced by treatment with $\beta$-adrenergic receptor agonists results in decreased leptin expression (Mantzoros et al. 1996, Slieker et al.
1996). It is known that galanin receptors are G-protein-coupled receptors and activation of GalR 1 results in inhibition of adenylyl cyclase through interaction with $\mathrm{G} \alpha \mathrm{i} / \mathrm{G} \alpha_{\mathrm{o}} \mathrm{G}$-proteins (Habert-Ortoli et al. 1994, Parker et al. 1995), therefore it is tempting to speculate that galaninrepressed leptin production may be mediated by changes in intracellular cAMP level. The belief that downstream signaling cascades of galanin receptor may be involved in the regulation of leptin secretion and mRNA expression needs further investigation.

In summary, we have found galanin and its receptors, GalR1 GalR2, were expressed in rat adipose tissue and 3T3-L1 adipocytes. Leptin mRNA and protein decreased in 3T3-L1 adipocytes when incubated with $10 \mathrm{nM}$ galanin. Treating rats with galanin decreased leptin protein secretion and inhibited leptin mRNA expression in visceral adipose tissues. Galanin mRNA expression was up-regulated in rat adipose tissue after fasting. These data suggest that galanin mRNA expressed in the visceral adipose tissue may be involved in the regulation of feeding and energy balance after fasting.

\section{Funding}

This work was supported in part by grants from the Foundation for the Author of National Excellent Doctoral Dissertation of People's Republic of China (200154) (H-D S), and the National Natural Science Foundation of China (30000082 and 30270626). All the funding mentioned in this article are supported by the government. There is no conflict of interest that would prejudice the impartiality of the research or a potential conflict of interest that is not fully declared within the text of the article.

\section{References}

Ahren B \& Lindskog S 1992 Galanin and the regulation of islet hormone secretion. International fournal of Pancreatology 11 147-160.

Barr VA, Malide D, Zarnowski MJ, Taylor SI \& Cushman SW 1997 Insulin stimulates both leptin secretion and production by rat white adipose tissue. Endocrinology $1384463-4472$.

Boden G, Chen X, Mozzoli M \& Ryan I 1996 Effect of fasting on serum leptin in normal human subjects. Fournal of Clinical Endocrinology and Metabolism 9 3419-3423.

Bradley RL \& Cheatham B 1999 Regulation of ob gene expression and leptin secretion by insulin and dexamethasone in rat adipocytes. Diabetes 48 272-278. 
Brann DW, Chorich LP \& Mahesh VB 1993 Effects of progesterone on galanin mRNA levels in the hypothalamus and pituitary: correlation with the gonadotropin surge. Neuroendocrinology $\mathbf{5 8}$ 531-538.

Chan YY, Grafstein-Dunn E, Delemarre-Van De Wall HA, Burton K \& Steiner RA 1996 The role of galanin and its receptor in the feedback regulation of growth hormone secretion. Endocrinology $1375303-5310$.

Considine RV, Sinha MK, Heiman ML, Kriauciunas A, Stephens TW, Nyce MR, Ohannesian JP, Marco CC, McKee LJ, Bauer TL et al. 1996 Serum immunoreactive-leptin concentrations in normal-weight and obese humans. New England Fournal of Medicine $5292-295$.

Ekblad E, Hakanson R, Sundier F \& Wahlestedt C 1985 Galanin: neuromodulatory and direct contractile effects on smooth muscle preparations. British Fournal of Pharmacology 86 241-246.

Flier JS \& Flier EM 1998 Obesity and the hypothalamus: novel peptides for new pathways. Cell 92 437-440.

Friedman JM \& Leibel RL 1992 Tackling a weighty problem. Cell $69217-220$.

Grundy SM \& Barnett JP 1990 Metabolic and health complications of obesity. Disease a Month 36 641-731.

Habert-Ortoli E, Amiranoff B, Loquet I, Laburthe M \& Mayaux JF 1994 Molecular cloning of a functional human galanin receptor. PNAS 91 9780-9783.

Hotamisligi G, Shargill N \& Spiegelman B 1993 Adipose expression of tumor necrosis factor-alpha: direct control in obesity-linked insulin resistance. Science 259 87-91.

Kim KH, Lee K, Moon YS \& Sul SH 2001 A cysteine-rich adipose tissue-specific secretory factor inhibits adipocyte differentiation. Fournal of Biological Chemistry 276 11252-11256.

Kirchgessner TG, Uysal T, Wiesbrock SM, Marino MW \& Hotamisligil GS 1997 Tumor necrosis factor- $\alpha$ contributes to obesity-related hyperleptinemia by regulating leptin release from adipocytes. Fournal of Clinical Investigation 100 2777-2782.

Maeda K, Okubo K, Shimomura I, Funahashi T, Matsuzawa Y \& Matsubara K 1996 cDNA cloning and expression of a novel adipose specific collagen-like factor, apMl (adipose most abundant gene transcript1). Biochemical and Biophysical Research Communications $221286-289$.

Mantzoros CS, Qu D, Friederich RC, Susulic VS, Lowell BB, Maratos-Flier E \& Flier JS 1996 Activation of beta(3) adrenergic receptors suppresses leptin expression and mediates a leptin-independent inhibition of food intake in mice. Diabetes $\mathbf{4 5}$ 909-914.

Merchenthaler I, Lopez FJ \& Negro-Vilar A 1993 Anatomy and physiology of central galanin-containing pathways. Progress in Neurobiology 40 711-769.

Murakami T, Iida M \& Shima K 1995 Dexamethasone regulates ob expression in isolated rat adipocytes. Biochemical and Biophysical Research Communications 214 1260-1267.
Parker EM, Izzarelli DG, Nowak HP, Mahle CD, Iben LG, Wang L \& Goldstein ME 1995 Cloning and characterization of the rat GALRl galanin receptor from Rinl2B insulinoma cells. Molecular Brain Research 34 179-189.

Pelleymounter MA, Cullen MJ, Baker MB, Hecht R, Winters D, Boone T \& Collins F 1995 Effects of the obese gene product on body weight regulation in ob/ob mice. Science $269549-543$.

Saladin R, De Vos P, Guerre-Millo M, Leturque A, Girard J, Staels B \& Auwerx J 1995 Transient increase in obese gene expression after food intake or insulin administration. Nature 377 527-529.

Schwartz MW, Sipols AJ, Grubin CE \& Baskin DG 1993 Differential effect of fasting on hypothalamic expression of genes encoding neuropeptide $\mathrm{Y}$, galanin, and glutamic acid decarboxylase. Brain Research Bulletin 31 361-367.

Schwartz MW, Woods SC, Porte D Jr, Seeley RJ \& Baskin DG 2000 Central nervous system control of food intake. Nature $\mathbf{4 0 4}$ 661-671.

Slieker LJ, Sloop KW, Surface PL, Kriauciunas A, Laquier F, Manetta J, Valleskey JB \& Stephens TW 1996 Regulation of expression of ob mRNA and protein by glucocorticoids and CAMP. Fournal of Biological Chemistry 271 5301-5304.

Tatemoto K, Rokaeus A, Jornwall H, McDonald TJ \& Mutt V 1983 Galanin-A novel biologically active peptide from porcine intestine. FEBS Letters 164 124-128.

Wang S, Ghibaudi L, Hashemi T, He C, Strader C, Bayne M, Davis H \& Hwa JJ 1998 The GalR2 galanin receptor mediates galanin-induced jejunal contraction, but not feeding behavior, in the rat: differentiation of central and peripheral effects of receptor subtype activation. FEBS Letters 434 277-228.

Waters SM \& Krause JE 2000 Distribution of galanin-1, -2 and -3 receptor messenger RNAs in central and peripheral rat tissues. Neurosicience 95 265-271.

Woods SC, Seeley RJ, Jr DP \& Schwartz MW 1998 Signals that regulate food intake and energy homeostasis. Science $\mathbf{2 8 0}$ $1378-1383$.

Yang YS, Song HD, Li RY, Zhou LB, Zhu ZD, Hu RM, Ha ZG \& Chen JL 2003 The gene expression profiling of human visceral adipose tissue and its secretory functions. Biochemical and Biophysical Research Communications 300 839-846.

Zhang B, Grziano MP, Doebber TW, Leibowitz MD, White-Carrington S, Szalkowski DM, Hey PJ, Wu M, Cullinan CA, Bailey P et al. 1996 Down-regulation of the expression of ob gene by an antidiabetic thiazolidione in Zucker diabetic fatty rats and db/db mice. Fournal of Biological Chemistry 271 9455-9459.

Zhang Y, Proenca R, Maffei M, Barone M, Leopold L \& Friedman JM 1994 Positional cloning of the mouse obese gene and its human homolog. Nature 372 425-432.

Received 19 February 2004

Accepted 23 March 2004 